\title{
Anti-hyperglycemic and Immunomodulatory Activity of a Polyherbal Composed of Sesbania grandiflora, Salacca zalacca and Acalypha indica
}

\author{
Ahmad Zamroni ${ }^{1,2 *}$, Elok Zubaidah², Muhaimin Rifa'i ${ }^{3}$, Simon Bambang Widjanarko ${ }^{2}$ \\ ${ }^{1}$ Department of Agricultural Product Technology, Samarinda State Agricultural Polytechnique, Samarinda, Indonesia \\ ${ }^{2}$ Department of Agricultural Product Technology, Faculty of Agricultural Technology, University of Brawijaya, Malang, \\ Indonesia \\ ${ }^{2}$ Departemant of Biology, Faculty of Mathematics and Natural Sciences, University of Brawijaya, Malang, Indonesia
}

\begin{abstract}
Diabetes has become a serious global public health problem due to its high prevalence and mortality. Unfortunately, current anti-diabetic drugs are having some limitations and adverse effects. Therefore, searching for a new anti-diabetic agent is an urgent challenge. In this research, we examined the effectiveness of a traditional anti-diabetic polyherbal composed of Sesbania grandiflora seeds, Salacca zalacca leaves and Acalypha indica roots (2:1:1). The study was aimed to explore the anti-hyperglycemic effect of the polyherbal in STZ-induced diabetic mice and to investigate the immunomodulatory activity involved in the process of controlling hyperglycemia. Our results showed that the polyherbal water extract ( $\left.150 \mathrm{mg}^{\mathrm{kgBW}}{ }^{-1}\right)$ could suppress blood glucose elevation and preserve pancreatic islet of diabetic mice. Moreover, the polyherbal treatment could normalize the relative amount of activated $\mathrm{CD} 4^{+} \mathrm{CD} 62 \mathrm{~L}^{-}$and $\mathrm{CD} 8{ }^{+} \mathrm{CD} 62 \mathrm{~L}^{-} \mathrm{T}$ cells. The polyherbal extract also stimulated the production of $\mathrm{CD}^{+}{ }^{+} \mathrm{CD} 25^{+} \mathrm{FoxP3}^{+}$regulatory $\mathrm{T}$ cells (Tregs) which is known to play an important role in diabetes control. In addition, polyherbal treatment also increased the relative amount of anti-inflammatory cytokines IL-10 and TGF- $\beta$. These results revealed that the polyherbal extract has an anti-hyperglycemic and immunomodulatory activity that may provide beneficial function in diabetes healing.
\end{abstract}

Keywords: Antidiabetes, Immunomodulator, Polyherbal, Regulatory T cell.

\section{INTRODUCTION}

Diabetes is a disease characterized by hyperglycemia [1]. It occurs due to inadequate peripheral tissue response to levels of insulin in the body, and/or by overall insufficient insulin production [2]. Diabetes can cause some serious health problems including of the damage of blood vessels, heart, kidneys, eyes, nerves, as well as increases the risk of stroke. Diabetes and related complications are also a prime cause of death [3]. The International Diabetes Federation (IDF) estimated that the total number of people with diabetes in the world was 415 million in 2015 and predicts this figure will increase to 642 million people in 2040. Because of its high rate of prevalence and mortality, diabetes has become one of the global health emergencies of the twenty-first century [4].

Currently, there are some approved drugs available to clinically treat diabetes. However, the use of those drugs has been reported to lead to undesirable side effects [5]. Moreover, these medicines do not significantly improve $\beta$ cell

\footnotetext{
* Correspondence address:

Ahmad Zamroni

Email : zam.ahzami@gmail.com

Address : Samarinda State Agricultural Polytechnique Jl. Samratulangi, Samarinda, East Kalimantan, Indonesia 75242.
}

function, so they cannot cure diabetes completely in a patient $[6,7]$. Contrastingly, many people have claimed to have recovered from diabetes by consuming plant-based herbal medicines as prescribed in traditional remedies. Unfortunately, most of their claims have not yet been supported by scientific evidence. Therefore, it is necessary to scientifically investigate antidiabetic activity resulting from plant-based herbals used in traditional diabetes remedies. This investigation is essential if there are to be discoveries of potential anti-diabetic agents that are more effective and safer than drugs available today.

Studies on diabetes have revealed the close link between immune system and diabetes pathology. It has been reported that proinflammatory markers were increase in diabetic patients [8,9]. Inflammatory cytokines also contributes to the onset of insulin resistance [10] and diabetic complications [11]. Based on these findings, a new stategy for diabetes treatment namely immunomodulatory theraphy was developed by using anti-inflammatory or other immunomodulatory agents [12]. Recent data revealed that immunomodulatory treatments could give beneficial effects on glycemia, $\beta$-cell function, and insulin resistance [13]. In accordance with this research, compounds 
contained in traditional anti-diabetic herbals could be expected to have immunomodulatory properties that may modulate immune system and further ameliorate diabetes symptoms.

In this study, we investigated scientific evidence of the effectiveness of an Indonesian traditional polyherbal composed of Sesbania grandiflora seeds, Salacca zalacca leaves and Acalypha indica roots (2:1:1) which has been used to combat diabetes by local people in Malang City, Indonesia. Originally, this polyherbal mixture was made by a traditional herbal practitioner who has more than 20 years of experience in composing various plant-based medicines. The study was aimed to investigate the anti-hyperglycemic effects of the polyherbal treatment in STZ-induced diabetic mice and to analyze the immune system modulation involved in the process of controlling hyperglycemia.

\section{MATERIAL AND METHOD \\ Materials}

Sesbania grandiflora (local name: turi, English name: hummingbird tree) seeds were purchased from a local agricultural seed supplier. Salacca zalacca (local name: salak, English name: snake fruit) leaves were taken from private local gardens in Pasuruan City, Indonesia (-7 ${ }^{\circ} 38^{\prime} 43.08^{\prime \prime}$ S $112^{\circ} 54^{\prime} 27.00^{\prime \prime} \mathrm{E}$ ). Acalypha indica (local name: anting-anting, English name: Indian nettle) roots were taken from local private gardens in Malang City, Indonesia (7055'23.61" S 11238'4.62" E). The plant names of materials used in this study have been checked with plant list species provided in http://www.theplantlist.org.

\section{Animals}

Animals used in this experiment were 10weeks old male BALB/c mice (Mus musculus Linnaeus) with an average body weight of $30 \pm 2$ $\mathrm{g}$. The mice were contained in individual cages at the animal experimentation laboratory of Biosains Institute, Brawijaya University.

\section{Induction of Diabetes}

Induction of diabetes was conducted by the method of Furman [14] with modification at the dose of STZ. The healthy non-diabetic mice were injected intraperitoneally with streptozotocin solution (Bioworld, USA) in a dose of $140 \mathrm{mg} . \mathrm{kg}^{-1}$. STZ solution was prepared immediately before injection by dissolving an appropriate amount of STZ powder with $10 \mathrm{mM} \mathrm{Na-citrate} \mathrm{buffer}(\mathrm{pH}$ 4.5) at a final concentration of $20 \mathrm{mg} \mathrm{STZ} \mathrm{mL}^{-1}$. In order to optimize STZ absorption, the mice were fasted for 4 hours prior to injection. At six days post-injection, blood glucose levels of the mice were measured with a glucometer device. Mice with glucose levels higher than $200 \mathrm{mg} \mathrm{dl}^{-1}$ were considered as diabetic mice.

\section{Preparation of Water Extract of Polyherbal}

The polyherbal mixture ingredients were washed with fresh water and left to dry outdoor for 24 hours. The materials were then dried in an oven (set at $120^{\circ} \mathrm{C}$ ) for 1 hour, and then each component was ground finely into a powder. The powders were then mixed in the ratio of $S$. gradiflora: S. zalacca: $A$. indica $=2: 1: 1$ as prescribed in the traditional polyherbal preparation.

Traditionally, the polyherbal decoction was prepared by pouring hot water into the powdered polyherbal mixture, and, once the mixture had cooled and the solid materials had settled, the decoction was consumed immediately. In this experiment, the polyherbal extract was prepared by dissolving the polyherbal powder into boiled water (at a ratio of 1:10) and then kept at room temperature for 24 hours. The solid sediment was then separated from aqueous extract. The liquid extract was then evaporated using a freeze dryer.

\section{Treatments}

Animals were divided into three groups. The first group was comprised of only normal mice (Non-diabetic Mice, NDM), the second group contained diabetic mice who were not being given treatment (Untreated Diabetic Mice, UTDM), and the third group was made up of diabetic mice who were administered with the polyherbal extract (Polyherbal-treated Diabetic Mice, PTDM). Six experimental mice were used for each group. The extract was administered once a day for 24 days orally using the gavage technique at a dose of $150 \mathrm{mg} \mathrm{kg}^{-1} \mathrm{BW}$.

\section{Blood Glucose Measurement}

The blood glucose level was measured with a glucometer (General Electric, USA) every six days. At the blood glucose readings, the tip of each mouse's tail was carefully snipped and then massaged until a small bead of blood had formed. The blood was then put on the test strip which was inserted into the glucometer device.

\section{Histology of Pancreatic Islet}

On day 25 of the study, the mice were sacrificed, then their pancreas was harvested and fixed in $10 \%$ formalin solution. The fixed pancreas specimens were then immediately sliced, processed and embedded into paraffin 
of Polyherbal (Zamroni et al)

blocks. The blocks were cut into $4 \mu \mathrm{m}$ paraffin sections by a rotator microtome and stained with Hematoxylin and Eosin (H\&E) [15]. The histological observation was done by using a light microscope.

\section{Isolation of Splenocytes and Flow Cytometry Analysis}

Isolation of splenocytes and flow cytometry analysis were performed according to the method of Rifa' $i$ and Widodo [16] with modification in the type of antibodies. Harvested mouse spleens were washed with sterile PBS twice and placed on a petri dish containing additional sterile PBS. The spleens were then pressed using a syringe holder. A single cell solution was filtered with a sterile wire and placed into a $15 \mathrm{~mL}$ polypropylene tube. PBS was added to this suspension till the $10 \mathrm{~mL}$ mark and then centrifuged at $2,500 \mathrm{rpm}$ at $4^{\circ} \mathrm{C}$ for five minutes. The supernatant was then discarded, and the obtained pellet was resuspended in $1 \mathrm{~mL}$ of sterile PBS. The single cell suspension containing around $2-3 \times 10^{6}$ cells was washed with PBS and stained with FITC-conjugated antimouse CD4, PE-conjugated anti-mouse CD8, PEconjugated anti-mouse CD25, PE/Cy5-conjugated anti-mouse CD62L.

Intracellular cytokine staining was performed with a Cytofix/Cytoperm kit (BD-Biosciences Pharmingen) according to the protocol provided by the manufacturer. Pellets with approximately $2-3 \times 10^{6}$ cells were stained with FITC-conjugated anti-mouse CD4 and PE-conjugated anti-mouse $\mathrm{CD} 25$ for $30 \mathrm{~min}$. After incubation, the suspension was washed, and the pellet was resuspended in cytofix buffer $(200 \mu \mathrm{L})$ for $20 \mathrm{~min}$ in the dark at $4^{\circ} \mathrm{C}$, then resuspended in $1 \mathrm{~mL}$ wash-perm and centrifuged again at $2500 \mathrm{rpm}$ at $4^{\circ} \mathrm{C}$ for $5 \mathrm{~min}$. The supernatant was discarded, and the obtained pellet was subjected to intracellular staining with PerCP anti-mouse FoxP3, PerCP anti-mouse interleukin-10 and $\mathrm{PE} / \mathrm{Cy} 5$ anti-mouse TGF- $\beta$ for 30 minutes.

\section{Data Analysis}

The data were analyzed using the one-way analysis of variance (ANOVA) to determine the significance of the difference between the means of the groups. A post hoc analysis was conducted according to Fisher's Least Significant Different (LSD) test at 95\% of confidence level. The ANOVA and LSD tests were performed using software Genstat 18th Edition (VSN International Ltd., UK).

\section{RESULT AND DISCUSSION}

Effect of Polyherbal Administration on Blood Glucose of Diabetic Mice

Figure 1 showed that the blood glucose of untreated diabetic mice increased to $487 \pm 38$ mg.dL ${ }^{-1}$ after 24 days of treatment. In the diabetic mice receiving polyherbal treatment, the blood glucose level was $313 \pm 19 \mathrm{mg} \cdot \mathrm{dL}^{-1}$ which were very significantly lower than that in diabetic control. This result indicates that polyherbal administration was able to prevent the blood glucose elevation in diabetic mice.

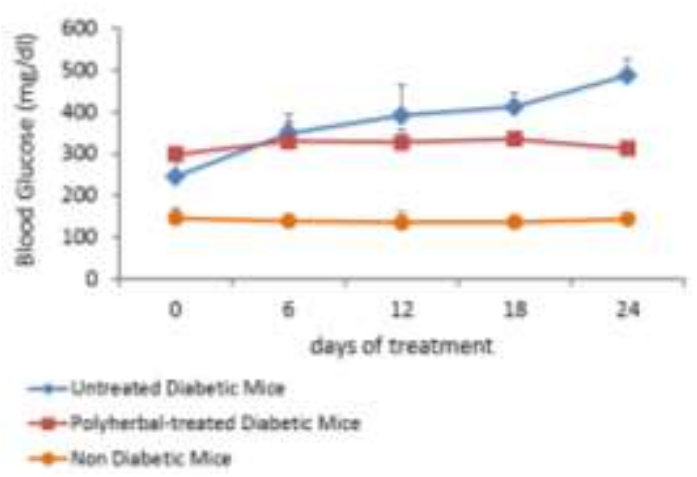

Figure 1. Blood Glucose (mg.dL-1 $)$ of Experimental Mice after 24 Days of Treatment.

The anti-hyperglycemic activity of polyherbal extract showed in this study was also supported by the histological observation of the pancreatic islet. The pancreas samples of normal mice showed a granular islet cells with a smooth edge (white arrow), while untreated diabetic mice showed an irregular shaped of a damaged islet which was red in color due to blood infiltration. On the other hand, the pancreas of diabetic mice receiving polyherbal extract treatment was partially recovered. A granular islet can be seen in the pancreas samples from polyherbal-treated mice, though the size was smaller than those from normal mice (Fig. 2).
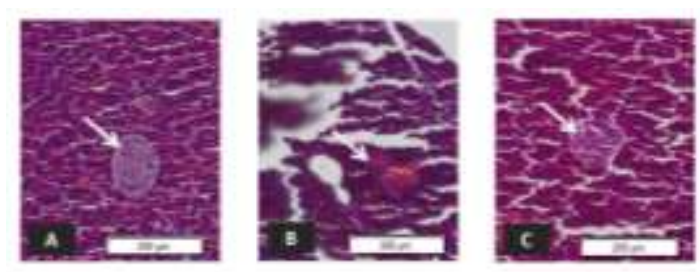

Figure 2. Photomicrograph of the Pancreas Sections. (A) Non-diabetic Mice, (B) Untreated Diabetic Mice and (c) Polyherbal-treated Diabetic Mice, stained by Hematoxylin and Eosin.

The ability of the polyherbal extract to prevent blood glucose elevation might be resulted from its immunomodulatory properties 
that contribute to pancreatic islet preservation after beta cells was destroyed by STZ toxicity. Previous studies showed that STZ could destroy pancreatic islet through necrosis mechanism [17, 18] followed by islet-specific autoreactivity after cellular debris from $\beta$ cells were presented on antigen presenting cells [19]. Interestingly, immunomodulatory therapy could restore selftolerance, causing the suppression of isletspecific autoimmune responses and prevention of $\beta$-cell destruction [20]. Moreover, therapy with immuno-modulatory agents is considered as a new prospective strategy that could give beneficial effects in the diabetes treatment [21, 12,13]. The immunomodulatory activity of polyherbal extract in this experiment are discussed in more detail in the subsections below.

\section{Effect of Polyherbal Administration on Relative Amount of Activated T Cells in Diabetic Mice}

The relative amount of $\mathrm{CD}^{+} \mathrm{CD} 62 \mathrm{~L}^{-}$and $\mathrm{CD}^{+} \mathrm{CD}^{2} 2 \mathrm{~L}^{-} \mathrm{T}$ cells in the diabetic mice were $73.55 \%$ and $71.24 \%$, respectively (Fig. 3). These values were significantly higher than that in the healthy mice (52.29\% and $47.69 \%$, respectively).
The increase of $\mathrm{CD}^{+} \mathrm{CD}^{-} 2 \mathrm{~L}^{-}$and $\mathrm{CD}^{+} \mathrm{CD} 62 \mathrm{~L}^{-} \mathrm{T}$ cells relative amount in the diabetic mice indicates that hyperglycemia stimulates activation of both $\mathrm{T}$ helper cells $\left(\mathrm{CD} 4^{+}\right)$and cytotoxic T cells $\left(\mathrm{CD} 8^{+}\right)$which were characterized by lost of their L-selectin (CD62L') from their surface. This result is similar to that found by Rifa' $i$ and Widodo [16] showing an increase of activated $T$ cells in the diabetic mice group. In addition, it has been found that diabetic patients have more pro-inflammatory markers than healthy people $[10,11]$.

Mature $T$ cells are developed in the thymus which is immunologically considered as naïve $T$ cells [22]. After naïve $T$ cells are released from the thymus gland, they circulate between the blood and lymph, making intermediate stops in the secondary lymphoid organs such as the spleen and lymph nodes. In secondary lymphoid organs, naïve T cells will be activated when they encounter mediators for $T$ cell activation. Once $T$ cells are activated, they lose their adhesion molecules $L$ selectin (CD62L) from their surface and induce other immune cells leading to inflammatory state $[23,24,25,26]$.
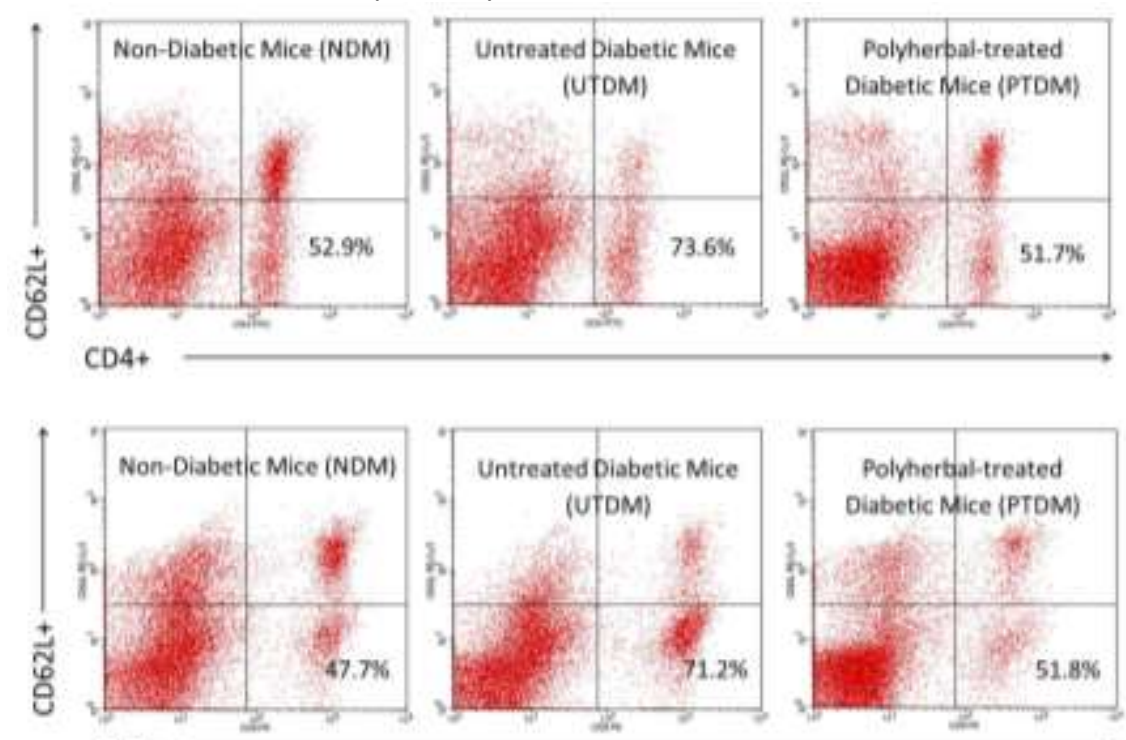

$\mathrm{CDB}+$
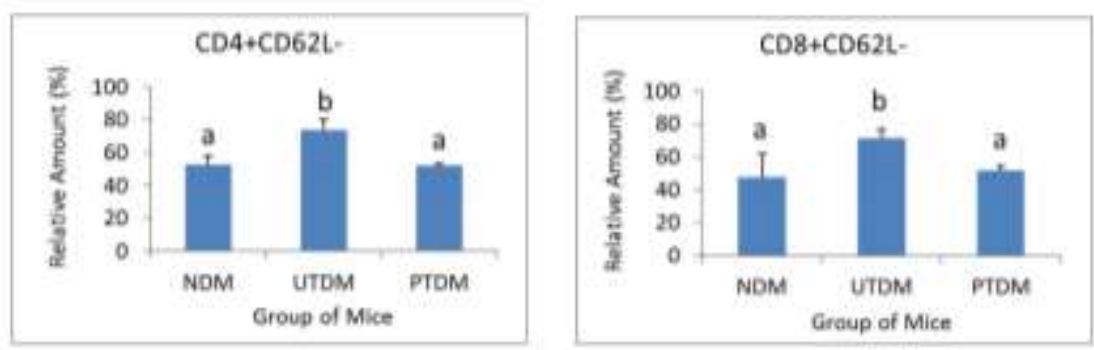

Figure 3. Relative Amount of Activated $\mathrm{CD}^{+}$and $\mathrm{CD}^{+} \mathrm{T}$ Cells in Experimental Mice after 24 Days of Treatment 
In the diabetic state, $T$ cells might be activated through hyperglycemia-induced oxidative stress [27] or by exposure of isletspecific antigens $[19,28]$. Although the precise mechanism is debatable, involvement of $\mathrm{T}$ cells auto-reactivity leading to $\beta$ cell self-destruction is evidenced both in mice and in human [29]. Based on this understanding, some trials have been conducted by targeting of T cells to induce $\beta$ cellspecific tolerance for diabetes treatment $[29,30]$.

Interestingly, administration of the polyherbal extract could lower the population of activated $T$ cells in diabetic mice to as low as the numbers in healthy mice (Fig. 3). This finding indicates that the polyherbal extract used in this study is a potential source of an immunomodulator, which may lead to benefit in the treatment of diabetes. Possibly, polyherbal suppress $T$ cell activation by decreasing oxidative stress facilitated by antioxidant compounds contained in the polyherbal extract. Alternatively, compounds in the polyherbal extract might stimulate the production of endogenous biological substances that act as immune suppressors such as regulatory $\mathrm{T}$ cell (Treg) and anti-inflammatory cytokines.

\section{Effect of Polyherbal Administration on Relative Amount of Regulatory T Cells in Diabetic Mice}

Recently, regulatory $T$ cells (Tregs) have become widely accepted as a new tool for understanding DM1 pathogenesis as well as giving new prospects in prevention and treatment of the disease [31]. Earlier studies $[32,33]$ have shown that the balance between effector Th cells and Tregs plays a role in diabetes progression. After the onset of diabetes, autoimmunity progression continuously increases as the increase of ratio between effector Th cells and Tregs occurs within an inflamed pancreas [34].

Tregs are characterized by a high constitutive surface expression of the IL-2 receptor alpha chain (IL2RA), which is also commonly called Cluster of Differentiation (CD)25. In addition, the expression of intracellular forkhead box protein 3(FOXP3) transcription factor is accepted as being the best marker of Treg cells [31,35].

In this study, the polyherbal administration was found to increase the relative amount of $\mathrm{CD}^{+} \mathrm{CD} 25^{+}$regulatory $\mathrm{T}$ cells (Tregs) in STZinduced diabetic mice. Specifically, $\mathrm{CD}^{+}{ }^{+} \mathrm{CD} 25^{+} \mathrm{FoxP}^{+}$Tregs level increased more than two-fold when compared to the diabetic control group (Fig. 4). These results indicate that polyherbal extract could stimulate the production of Treg cells. Regarding the important role of Tregs in T1D, boosting Tregs number may provide an effective aspect of diabetes treatment $[36,37]$.

The role of Tregs in diabetes treatment is correlated with its immunomodulatory function which suppresses the excessive responses of immune cells in both innate and adaptive immune systems. Previous research has revealed that $\mathrm{CD}^{+} \mathrm{CD} 25^{+}$Treg could suppress $\mathrm{CD} 4^{+}$and $\mathrm{CD} 8^{+}$ $\mathrm{T}$ cells proliferation and their pro-inflammatory cytokines production in addition to suppressing their effector activities such as $\mathrm{CD}^{+} \mathrm{T}$ cell cytotoxicity [38]. Various immune cells that are suppressed by Tregs include T cells, B cells, natural killer, macrophage, neutrophils, dendritic cells and mast cells [39]. In this study, the contribution of Tregs to the suppression of $T$ cell activation could be seen in polyherbal-treated diabetic mice as shown in Figure 3.

To our knowledge, this is the first study that showed stimulation of Tregs induction by using polyherbal composed of S. grandiflora, S. zalacca, and $A$. indica. However, several studies have been done on Tregs induction by using other medicinal herbals. Licorice (the root of Glycyrrhiza species) extract, and its two constituents, isoliquiritigenin, and naringenin have been proved to effectively promote Treg cell production both in vitro and in vivo [40]. Other studies also reported that some medicinal plants and their derivatives, including Astragalus membranaceus, Pterodon emarginatus Vogel, Hypericum perforatum, hyungbangpaedok-san, matrine, Bu Shen Yi Sui Capsule, resveratrol, and curcumin could induce Tregs production and increase its functional activities [41].

\section{Effect of Polyherbal Administration on Anti- inflammatory Cytokines Production}

Several mechanisms have been proposed as being explanations of the suppressive effect of regulatory $T$ cells. One of these Tregs suppressive mechanisms is done by anti-inflammatory cytokines secretion. Based on cytokine production, Tregs have been classified as follows: (1) Th3 cells which are characterized by TGF- $\beta$ production; (2) Tr1 cells which produce IL-10, and (3) Tr35 cells which produce IL-35 [42]. In this study, IL-10 and TGF- $\beta$ produced by $\mathrm{CD} 4^{+} \mathrm{CD} 25^{+}$regulatory $\mathrm{T}$ cells in polyherbal treated diabetic mice showed an increase relative to those in the untreated diabetic control and normal control groups (Fig. 5). This result is 
consistent with the finding of an overall increase of Tregs in polyherbal-treated diabetic mice as described above (Fig. 4).

In addition to its suppressive effect, IL-10 also plays a role in the process of cell regeneration. The ability of IL-10 to promote regenerative healing is most likely a result of its synergistic multiple actions including regulation of inflammatory response, endothelial progenitor cells, fibroblast cellular function, and extracellular matrix [43].
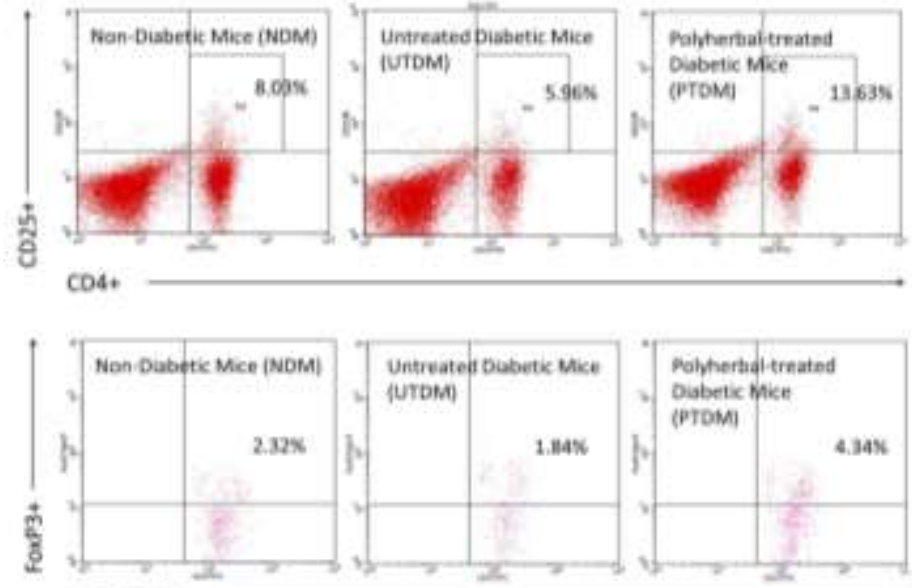

$\mathrm{CD} 4+\mathrm{CD} 25+$
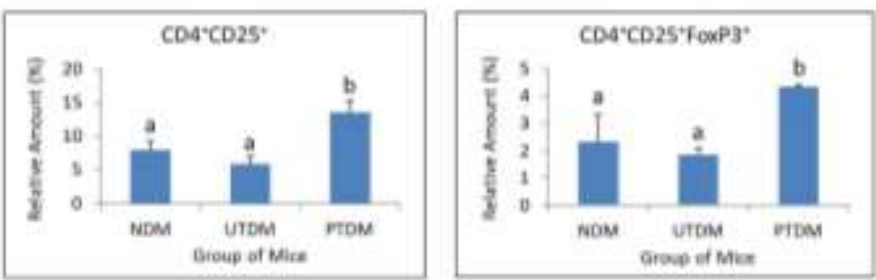

Figure 4. Relative Amount of Regulatory T Cells in Experimental Mice after 24 Days of Treatment
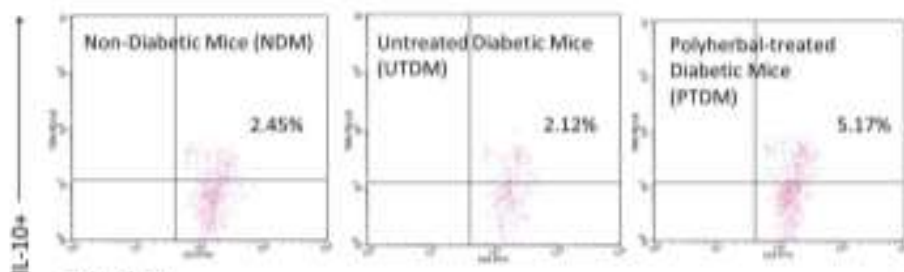

$\mathrm{CD} 4+\mathrm{CD} 25+$
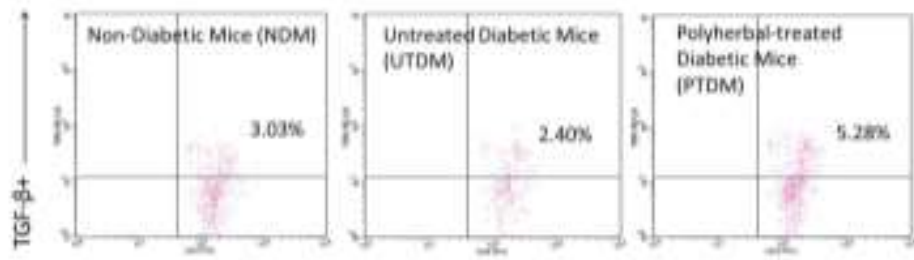

$\mathrm{CD} 4+\mathrm{CD} 25+$
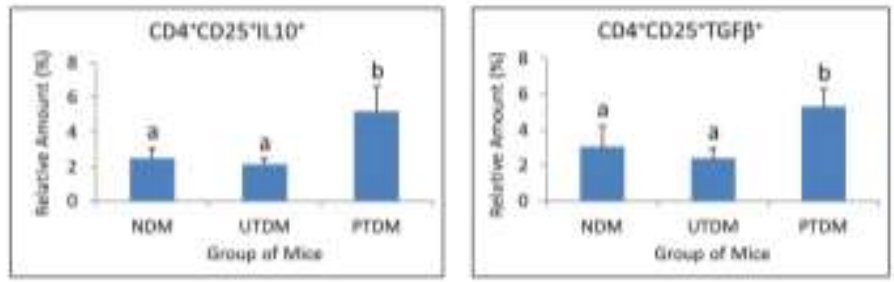

Figure 5. Relative Amount of Pro-inflammatory Cytokines in Experimental Mice after 24 Days of Treatment. 
Endogenous IL-10 limits the severity of fibrosis and glandular atrophy as well as regulates cell regeneration in experimental chronic pancreatitis [44]. Therefore, we suggest that IL-10 might help the process of pancreas regeneration after STZ destruction so that polyherbal- treated diabetic mice could partially recover their islet cells as shown in Figure 2 above. However, more in-depth research is needed to prove this speculation.

\section{CONCLUSION}

Water extract from a polyherbal mixture containing Sesbania grandiflora seeds, Salacca zalacca leaves and Acalypha indica roots (2:1:1) was proven to be able to prevent the progression of blood glucose elevation in STZ induced diabetic mice. The pancreatic islet of polyherbaltreated diabetic mice was also found to be partially recovered from the damage of diabetes induction. Furthermore, this study highlighted the significant increase of regulatory $T$ cells and anti-inflammatory cytokines production after polyherbal administration which contributes to lowering the relative amount of activated T cell in diabetic mice. These results revealed that the polyherbal extracts have an anti-hyperglycemic effect and that the polyherbal treatment could modulate the immune system of diabetic mice contributing to the process of controlling hyperglycemia.

\section{ACKNOWLEDGEMENT}

This work was financed by the Ministry of Technology, Research and Higher Education of Republic of Indonesia (Contract Number SP DIPA042.06.1.401516/2017).

\section{ETHICAL APPROVAL}

This experiment has been reviewed and legalized by the Ethics Committee of the Brawijaya University, Indonesia. All procedures performed in this experiment were in accordance with the guidelines and ethical standards of the Ethics Committee of Brawijaya University.

\section{REFERENCES}

[1] American Diabetes Association. 2012. Diagnosis and classification of diabetes mellitus. Diabetes Care. 35(1). S64-S71.

[2] Ruderman, N.B., S. Gupta, I. Sussman. 1992. Hyperglycemia, diabetes, and vascular disease: an overview. In: Ruderman, N., J. Williamson, M. Brownlee (Eds). Hyperglycemia, Diabetes, and Vascular Disease. Springer. New York.

[3] World Health Organization. 2016. Global report on diabetes. WHO Press. Geneva.

[4] International Diabetes Federation. 2015. Diabetes atlas, $7^{\text {th }}$ Ed. International Diabetes Federation. Brussels, Belgium.

[5] Alhadramy, M.S. 2016. Diabetes and oral therapies: a review of oral therapies for diabetes mellitus. J. Taibah Univ. Med. Sci. 11(4). 317-329.

[6] Li, W.L., H.C. Zheng, J. Bukuru, N. De Kimpe. 2004. Natural medicines used in the traditional Chinese medical system for therapy of diabetes mellitus. J. Ethnopharmacol. 92(1). 1-21.

[7] Sena, C.M., C.F. Bento, P. Pereira, R. Seica. 2010. Diabetes mellitus: new challenges and innovative therapies. EPMA Journal 1(1). 138-163.

[8] Esposito, K., F. Nappo, F. Giugliano, C.D. Palo, M. Ciotola, M. Barbieri, G. Paolisso, D. Giugliano. 2003. Cytokine milieu tends toward inflammation in type 2 diabetes. Diabetes Care. 26(5). 1647-1647.

[9] De Rekreneire, N., R. Peila, J. Ding, L.H. Colbert, M. Visser, R.I. Shorr, S.B. Kritchevsky, L.H. Kuller, E.S. Strotmeyer, A.V Schwartz, B. Vellas, T.B. Harris. 2006. Diabetes, hyperglycemia, and inflammation in older individuals. Diabetes Care. 29(8). 1902-1908.

[10] Borst, S.E. 2004. The role of TNF-alpha in insulin resistance. Endocrine. 23. 177-182.

[11] King, G.L. 2008. The role of inflammatory cytokines in diabetes and its complications. J. Periodontol. 79(8). 1527-1534.

[12] Tooley, J.E., F. Waldron-Lynch, K.C. Herold. 2012. New and future immunomodulatory therapy in type 1 diabetes. Trends Mol. Med. 18(3). 173-181.

[13] Pollack, R.M., M.Y. Donath, D. LeRoith, G. Leibowitz. 2016. Anti-inflammatory agents in the treatment of diabetes and its vascular complications. Diabetes Care. 39(2). 244-252.

[14] Furman, B.L. 2015. Streptozotocin-induced diabetic models in mice and rats. Curr. Protoc. Pharmacol. 70(5.47)1-20.

[15] Bancroft, J.D., M. Gamble. 2008. Theory and practice of histological techniques, $6^{\text {th }}$ Ed. Churchill Livingstone. Philadelphia, USA.

[16] Rifa'i, M., N. Widodo. 2014. Significance of propolis administration for homeostasis of CD4+CD25+ immunoregulatory $T$ Cells controlling hyperglycemia. SpringerPlus. 3. 526.

[17] Szkudelski, T. 2001. The mechanism of 
alloxan and streptozotocin action in B Cells of the rat pancreas. Physiol. Res. 50. 536546.

[18] Lenzen, S. 2008. The mechanisms of alloxan- and streptozotocin-induced diabetes. Diabetologia. 51. 216-226.

[19] Horwitz, M.S., A. Ilic, C. Fine, E. Rodriguez, N. Sarvetnick. 2002. Presented antigen from damaged pancreatic $\beta$ Cells activates autoreactive $\mathrm{T}$ Cells in virus-mediated autoimmune diabetes. J. Clin. Invest. 109. 79-87.

[20] Waldron-Lynch, F., K.C. Herold. 2011. Immunomodulatory Therapy to Preserve Pancreatic $\beta$-cell Function in Type 1 Diabetes. Nat. Rev Drug Discov 10: 439-452.

[21] Donath, M.Y. 2014. Targeting inflammation in the treatment of type 2 diabetes: time to start. Nat. Rev. Drug Discov. 13(6). 465-476.

[22] Berard, M., D.F. Tough. 2002. Qualitative differences between naïve and memory $T$ cells. Immunology. 106. 127-138.

[23] Mondino, A., A. Khoruts, M.K. Jenkins. 1996. The anatomy of T-cell activation and tolerance. Proc. NatI. Acad. Sci. USA. 93(6). 2245-2252.

[24] Yang, S., F. Liu, Q.J. Wang, S.A. Rosenberg, R.A. Morgan. 2011. The shedding of CD62L (L-Selectin) regulates the acquisition of lytic activity in human tumor reactive $T$ lymphocytes. PLos One. 6(7). e22560.

[25] Pepper, M., M.K. Jenkins. 2014. Origins of CD4+ effector and central memory T Cells. Nat. immunol. 12(6). 467-471.

[26] Golubovskaya, V., L. Wu. 2016. Different subsets of $T$ cells, memory, effector functions, and CAR-T immunotherapy. Cancers. 8. 36.

[27] Stenz, F.B., A.E. Kitabchi. 2005. Hyperglycemia-induced activation of human T-lymphocytes with de novo emergence of insulin receptors and generation of reactive oxygen species. Biochem. Biophys. Res. Commun. 335. 491-495.

[28] Kantwerk-Funke, G., V. Burkart, H. Kolb. 1991. Low dose streptozotocin causes stimulation of the immune system and of anti-islet cytotoxicity in mice. Clin. Exp. Immunol. 86(2). 266-270.

[29] Tsai, S., A. Shameli, P. Santamaria. 2008. CD8+ T cells in type 1 diabetes. Adv. Immunol. 100. 79-124.

[30] Xu, D., S. Prasad, S.D. Miller. 2013. Inducing immune tolerance: a focus on type 1 diabetes mellitus. Diabetes Manag. (Lond)
3(5). 415-426.

[31] Paschou, S.A., S. Tigas, K. Naka, G.K. Papadopoulos, A. Tsatsoulis. 2012. The role of $T$ regulatory cells (Tregs) in the development and prevention of type 1 diabetes. J. Clin. Cell Immunol. S2. 003.

[32] Salomon, B., D.J. Lenschow, L. Rhee, N. Ashourian, B. Singh, A. Sharpe, J.A. Bluestone. 2000. B7/CD28 costimulation is essential for the homeostasis of the $\mathrm{CD} 4^{+} \mathrm{CD} 25^{+}$immunoregulatory $\mathrm{T}$ Cells that control autoimmune diabetes. Immunity. 12(4). 431-440.

[33] Green, E.A., Y. Choi, R.A. Flavell. 2002. Pancreatic lymph node-derived CD4+CD25+ Treg cells: highly potent regulators of diabetes that require TRANCE-RANK signals. Immunity. 16(2). 183-191.

[34] Bour-jordan, H., B.L. Salomon, H.L. Thompson, G.L. Szot, M.R. Bernhard, J.A. Bluestone. 2004. Costimulation controls diabetes by altering the balance of pathogenic and regulatory T Cells. J. Clin. Invest. 114(7). 979-987.

[35] Pereira, L.M.S., S.T.M. Gomes, R. Ishak, A.C.R. Vallinoto. 2017. Regulatory T Cell and Forkhead Box Protein 3 as modulators of immune homeostasis. Front Immunol. 8. 605.

[36] Spence, A., Q. Tang. 2016. Restoring regulatory T cells in type 1 diabetes. Curr. Diab. Rep. 16. 110.

[37] Visperas, A., D.A.A. Vignali. 2016. Are regulatory $T$ cells defective in type 1 diabetes and can we fix them? J. Immunol. 197. 3762-3770.

[38] Sakaguchi, S., K. Wing, Y. Onishi, P. Prietomartin, T. Yamaguchi. 2009. Regulatory T cells: how do they suppress immune responses? Int. Immunol. 21(10). 11051111.

[39] Marek-Trzonkowska, N., M. Mysliwec, J. Siebert, P. Trzonkowski. 2013. Clinical application of regulatory T Cells in type 1 diabetes. Pediatr. Diabetes. 14. 322-332.

[40] Guo, A., D. He, H.B Xu, C.A. Geng, J. Zhao. 2015. Promotion of regulatory $T$ cell induction by immunomodulatory herbal medicine licorice and its two constituents. Sci. Rep. 5. 14046.

[41] Sani, M.R.M., M.A. Samani, H.R. Boroujeni, M.B. Dehkordi. 2016. Phytopharmacology and phytotherapy of regulatory T Cells: a new approach to treat multiple sclerosis. Pharm. Lett. 8(3). 215-220. 
[42] Arce-sillas, A., D.D. Álvarez-luquín, B. Tamaya-domínguez, S. Gomez-fuentes, A. Trejo-garcía, M. Melo-salas, G. Cárdenas, J. Rodríguez-ramírez, L. Adalid-peralta. 2016. Regulatory $T$ cells: molecular actions on effector cells in immune regulation. J. Immunol. Res. Article ID 1720827.

[43] King, A., S. Balaji, L.D. Le, T.M. Crombleholme, S.G. Keswani. 2014. Regenerative wound healing: the role of Interleukin-10. Adv. Wound Care 3(4). 315323.

[44] Demols, A., J.V. Laethem, E. Quertinmont, C. Degraef, M. Delhaye, A. Geerts, J. Deviere. 2002. Endogenous interleukin-10 modulates fibrosis and regeneration in experimental chronic pancreatitis. Am. J. Physiol-Gastr. L. 282(6). 1105-1112. 